\title{
Histometric Study of the Pituitary in Mice Treated Neonatally with Steroids and the Relationship between Prolactin Cells and Mammary Tumorigenesis
}

\author{
Seitchiro KAWASHIMA ${ }^{1}$, Howard A. BERN ${ }^{2}$, Lovell \\ A. JONES ${ }^{2 *}$ AND KAREN T. MILLS ${ }^{2}$ \\ ${ }^{1}$ Zoological Institute, Faculty of Science, University of Tokyo \\ Tokyo 113, and ${ }^{2}$ Department of Zoology and Cancer Research \\ Laboratory, University of California, Berkeley, California 94720
}

\begin{abstract}
Synopsis
Neonatal female mice of the $\mathrm{BALB} / \mathrm{cfC} 3 \mathrm{H} / \mathrm{Crgl}$ strain were given daily injections of $17 \beta$-estradiol, progesterone and prolactin, singly and in some combinations, for 5 days beginning within $36 \mathrm{hr}$ after birth. Mice were killed at tumor age or by 12 months of age. Differential cell counts of the anterior pituitary showed that prolactin cells were more numerous in neonatally estrogen-treated mice and progesteronetreated intact mice than in control mice. Paired analysis of tumor-bearing and nontumor-bearing mice of all groups revealed that the occurrence of prolactin cells was greater in the former than the latter. Counts of gonadotropes and thyrotropes did not show any significant correlation with mammary tumorigenesis. However, neonatal estrogen and/or progesterone treatment resulted in significantly decreased numbers of gonadotropes in intact mice. In ovariectomized mice, gonadotropes were significantly increased regardless of neonatal treatment. The present results support the suggestion that the stimulatory effects of neonatal steroid treatment of mammary tumorigenesis may be a consequence of increased prolactin secretion, resulting from sustained minimal estrogen secretion by the ovary.
\end{abstract}

Induction of persistent proliferation and cornification of the vaginal epithelium in female mice by neonatal steroid treatment has been well documented (for reviews: Bern et al., 1975 and 1976; Takasugi, 1976). However, until recently, relatively limited attention has been paid to the influence of neonatal exposure to steroid hormones on mammary tumorigenesis. Mori (1968a and $b$ ) reported that female $\mathrm{C} 3 \mathrm{H} / \mathrm{MS}$ mice receiving 0.5 or $20 \mu \mathrm{g} 17 \beta$-estradiol daily for the first 7-10 days of life showed elevated mammary tumor incidences. The development of mammary tumors in mice is dependent on the presence of mammary

\footnotetext{
Received October 3, 1977.

* Present address: Department of Obstetrics and Gynecology, University of California, San Francisco, California.
}

tumor virus (MTV); consequently, MTVexpressed $\mathrm{BALB} / \mathrm{cfC} 3 \mathrm{H}$ mice have been used to study the effects of perinatal steroid hormone exposure on subsequent development of mammary tumors. Mori et al. (1976) and Jones and Bern (1977) reported that neonatal administration of estrogen, androgen, progestin and estrogen-progestin combinations to $\mathrm{BALB} / \mathrm{cfC} 3 \mathrm{H}$ mice generally resulted in significantly higher mammary tumor incidences with a significantly earlier age of tumor onset when compared with control mice. In all cases, the presence of the ovary as well as MTV is required for tumor development.

There is ample evidence in mice and rats that prolactin is an important hormone in mammary tumorigenesis. Estrogen has also been shown to play a central role in 
mammary tumorigenesis, both directly (in rats) and indirectly (in rats and mice) by stimulating increased pituitary secretion of prolactin (Beuving and Bern, 1972; Meites and Clemens, 1972; Meites et al., 1972; Horrobin, 1973). Prolonged elevation of plasma prolactin experimentally induced by pituitary transplantation leads to an increase in mammary tumor incidence (Loeb and Moskop Kirtz, 1939; Mühlbock and Boot, 1959; Liebelt and Liebelt, 1961; Heston, 1964; Welsch et al., 1970a and b; Yanai and Nagasawa, 1972). A sustained increase in prolactin synthesis and release occurs after estradiol or testosterone treatment of neonatal rats (Neill, 1972; Pantíc and Genbačev, 1972; Mallampati and Johnson, 1973; Nagasawa et al., 1973).

The present study was undertaken to determine if there was a significant effect of neonatal hormone treatments on pituitary histology in $\mathrm{BALB} / \mathrm{cfC} 3 \mathrm{H}$ mice, particularly of the prolactin cells, and whether there was a relationship between prolactin cell numbers and mammary tumorigenesis.

\section{Materials and Methods}

The 239 pituitaries studied were collected from female $\mathrm{BALB} / \mathrm{cfC} 3 \mathrm{H} / \mathrm{Crgl}$ mice used in investigations of the effects of neonatal steroid treatment on the genital tract and mammary gland (Mori et al., 1976; Jones and Bern, 1977). Experimental animals were given 5 daily subcutaneous injections of hormones beginning within $36 \mathrm{hr}$ of birth. Daily doses were 5 or $20 \mu \mathrm{g} 17 \beta$-estradiol in $0.02 \mathrm{ml}$ sesame oil, $100 \mu \mathrm{g}$ progesterone in $0.02 \mathrm{ml}$ oil, or 5 or $20 \mu \mathrm{g}$ ovine prolactin in $0.02 \mathrm{ml}$ saline. Table 1 lists the 11 experimental groups. $17 \beta$-Estradiol was administered to mice in Groups $2-6,8$ and 9 singly or in combination with prolactin or progesterone. When $17 \beta$ estradiol was given with progesterone, both steroids were dissolved in $0.02 \mathrm{~m} l$ sesame oil (Groups 8 and 9). Animals receiving $0.02 \mathrm{~m} l$ sesame oil or $0.02 \mathrm{ml}$ saline served as controls (Group 1). Some mice in each treatment group were ovariectomized at 40 days of age. Autopsies were carried out in most animals when mammary tumors developed or at 1 year of age.

The pituitaries were fixed in Bouin-Hollande-sub- limate fluid for $24 \mathrm{hr}$ and embedded in paraffin. Sections $4-5 \mu \mathrm{m}$ thick were cut frontally and separated into 2 series. One series of sections was stained to demonstrate carmoisine L-positive cells (referred to as prolactin cells) with the method of El Etreby and Tüshaus (1973). The other series of sections was stained by the alcian blue-periodic acid-Schiff (AB-PAS) method (Herlant, 1960) to differentiate gonadotropes and thyrotropes in the same section. The preparations did not always show consistent tinctorial properties. A few unfavorable preparations were eliminated from cell counting. This elimination accounts for the differences in the numbers of animals per group given in Tables 1-3.

In the carmoisine $\mathrm{L}$ preparations, two types of acidophils, carmoisine L-positive cells and orange G-positive cells, were evident (Figs. 1-4). These cells were considered as prolactin cells and somatotropes, respectively (Brooks, 1968; El Etreby and Tüshaus, 1973). There were considerable numbers of cells showing staining intermediate between the typical carmoisine L-positive red cells and the typical orange G-positive cells. Cells that could not be classified definitely as "prolactin" cells were not included in the counts. In AB-PAS preparations, Herlant (1960) claimed that thyrotropes stained deep violet, LH cells brick red and FSH cells purple. These three types of basophils were regularly identified in the present experiments. However, 'LH' and ' $\mathrm{FSH}$ ' cells were combined herein and designated simply as gonadotropes.

Differential counting of the two types of basophils and of prolactin cells was performed following the procedures of Rasmussen and Herrick (1922) with some modifications. Instead of counting cells within an entire oil immersion field, the number of cells in the field limited by a grid ocular micrometer was counted at a magnification of $1,000 \mathrm{X}$. Both halves of the pituitary gland were counted at 3 different levels. A total of 15-14 fields was chosen for each pituitary, each field consisting of about 150 cells. Statistical analysis of the data was performed with the Student $t$ test

\section{Results}

\section{Mammary Tumor Incidence}

Table 1 shows the numbers of mice and the mammary tumor incidences in the several treatment groups studied herein. Neonatal treatments with estradiol (with and without prolactin, Groups 2-6), progesterone (Group 7) and estradiol plus progesterone (Groups 8 and 9) resulted in overall tumor incidence significantly greater 
Table 1. Numbers and ages of mice used

\begin{tabular}{|c|c|c|c|c|c|c|c|c|c|c|c|c|c|}
\hline \multirow{2}{*}{ Group } & \multirow{2}{*}{\multicolumn{3}{|c|}{$\begin{array}{l}\text { Neonatal } \\
\text { treatment }^{1)}\end{array}$}} & \multicolumn{9}{|c|}{ Intact } & \multirow{2}{*}{$\begin{array}{l}\text { ovariectomized }^{2)} \\
\text { (No.) }\end{array}$} \\
\hline & & & & Total & MT absent & \multicolumn{5}{|c|}{ MT presen } & at & MT present & \\
\hline 1 & & & & & & & & & & & & & 12 \\
\hline 2 & & - & - & 42 & 33 & 0 & & 0 & 1 & 0 & 0 & $14(78)$ & $\begin{array}{r}12 \\
5\end{array}$ \\
\hline 3 & $\begin{array}{l}5 \\
5\end{array}$ & - & - & 18 & 4 & 1 & 3 & 0 & 4 & 0 & 6 & $14(78)$ & $\begin{array}{l}5 \\
5\end{array}$ \\
\hline 4 & $\begin{array}{l}5 \\
5\end{array}$ & - & 5 & 8 & 6 & 0 & 0 & 0 & 0 & 0 & 2 & $2(25)$ & $\begin{array}{l}5 \\
9\end{array}$ \\
\hline 5 & $\begin{array}{r}5 \\
20\end{array}$ & - & 20 & 10 & 8 & 0 & 0 & 0 & 0 & 0 & 2 & $2(20)$ & 9 \\
\hline 6 & $\begin{array}{l}20 \\
20\end{array}$ & 一 & 一 & 7 & 3 & 0 & 0 & 0 & 0 & 0 & 4 & $4(57)$ & $\begin{array}{l}3 \\
9\end{array}$ \\
\hline Groups & & - & 20 & 12 & 8 & 0 & 0 & 0 & 0 & 1 & 3 & $\begin{array}{r}4(33) \\
-137)\end{array}$ & ( \\
\hline 7 & $2-0$ & & ned & 55 & 29 & 1 & 3 & 0 & 4 & 1 & 17 & $\begin{array}{l}26(47) \\
15(71)\end{array}$ & $\begin{array}{r}31 \\
0\end{array}$ \\
\hline 8 & $\overline{5}$ & 100 & - & 21 & 6 & 1 & 0 & ? & $\begin{array}{l}2 \\
5\end{array}$ & 1 & $\begin{array}{l}5 \\
2\end{array}$ & $11(55)$ & $\begin{array}{l}0 \\
4\end{array}$ \\
\hline 9 & 20 & 100 & 一 & 20 & 9 & 0 & $\begin{array}{l}2 \\
2\end{array}$ & 2 & 2 & 2 & 1 & $9(90)$ & $\begin{array}{l}4 \\
2\end{array}$ \\
\hline Groups & 8 anc & 100 & - & & & 0 & 4 & 4 & 7 & 2 & 3 & $20(67)$ & 6 \\
\hline 10 & - & - & $\begin{array}{l}\text { moined } \\
5\end{array}$ & $\begin{array}{l}30 \\
10\end{array}$ & $\begin{array}{r}10 \\
8\end{array}$ & 0 & 1 & 0 & 0 & 0 & 1 & $2(20)$ & $\begin{array}{r}0 \\
10\end{array}$ \\
\hline 11 & 一 & - & 20 & 8 & 8 & 0 & 0 & 0 & 0 & 0 & 0 & $0(0)$ & 14 \\
\hline Groups & 10 ar & d 11 & combined & 18 & 16 & 0 & 1 & 0 & 0 & 0 & 1 & $2(11)$ & 24 \\
\hline
\end{tabular}

1) Injections for the first 5 days of life. For details, see text.

2) Ovariectomy at 40 days of age; no tumors occurred in any group.

Abbreviations: E, 17 $\beta$-estradiol; P, progesterone; PRL, ovine prolactin;

$5,5 \mu \mathrm{g} /$ day in $0.02 \mathrm{~m} l$ vehicle; $20,20 \mu \mathrm{g} /$ day in $0.02 \mathrm{ml}$ vehicle;

MT, mammary tumor; m, months.

than in the mouse groups not treated with steroids. In addition, ages of tumor onset were significantly lower after neonatal steroid treatment.

\section{Differential Pituitary Cell Counts}

Figures 1-4 show the typical carmoisin L-positive cells (prolactin cells) in the tumor-free control mice (Figs. 1 and 2) and in the tumor-free mice subjected to neonatal treatment with $5 \mu \mathrm{g}$ estradiol (Figs. 3 and 4). Table 2 shows the mean prolactin cell counts (expressed as percentages of total pituitary cells) in the several groups. Neonatal treatment with 5 or $20 \mu \mathrm{g}$ estradiol with or without concomitant treatment with prolactin (combined Groups 2-6) resulted in a significantly greater number of prolactin cells than was seen in the controls $(\mathrm{p}<0.01)$. This increase also occurred in progesterone-treated mice (Group 7, $\mathrm{p}<$ 0.005 ) and in mice treated with estradiol plus progesterone $(\mathrm{p}<0.001)$. In prolactintreated groups (combined Groups 10 and 11), the prolactin cell counts were not significantly different from the control value.
Ovariectomy at day 40 resulted in a marked decrease in prolactin cells, significant in most groups tested, and abolished the effect of neonatal steroid treatment.

The mean prolactin cell count for mammary tumor-bearing mice is significantly higher than that for tumor-free mice in the control group $(\mathrm{p}<0.05)$ but not for any other individual groups. Prolactin combined with estradiol did not appear to modify the effect of estradiol alone, nor did the prolactin alone have any effect. The estradiol+ prolactin-treated groups were therefore combined with the groups given estradiol alone (combined Groups 2-6). In Groups 2-6, the prolactin cell count in tumor-bearing mice was significantly greater than that in non-tumor-bearing mice $(\mathrm{p}<$ 0.01 , Table 2). There was no significant difference between tumor-bearing and tumorfree mice given estradiol plus progesterone neonatally (combined Groups 8 and 9). However, paired analysis of group means from tumor-bearing and non-tumor-bearing mice in all groups showed that the prolactin cell count was significantly higher in 


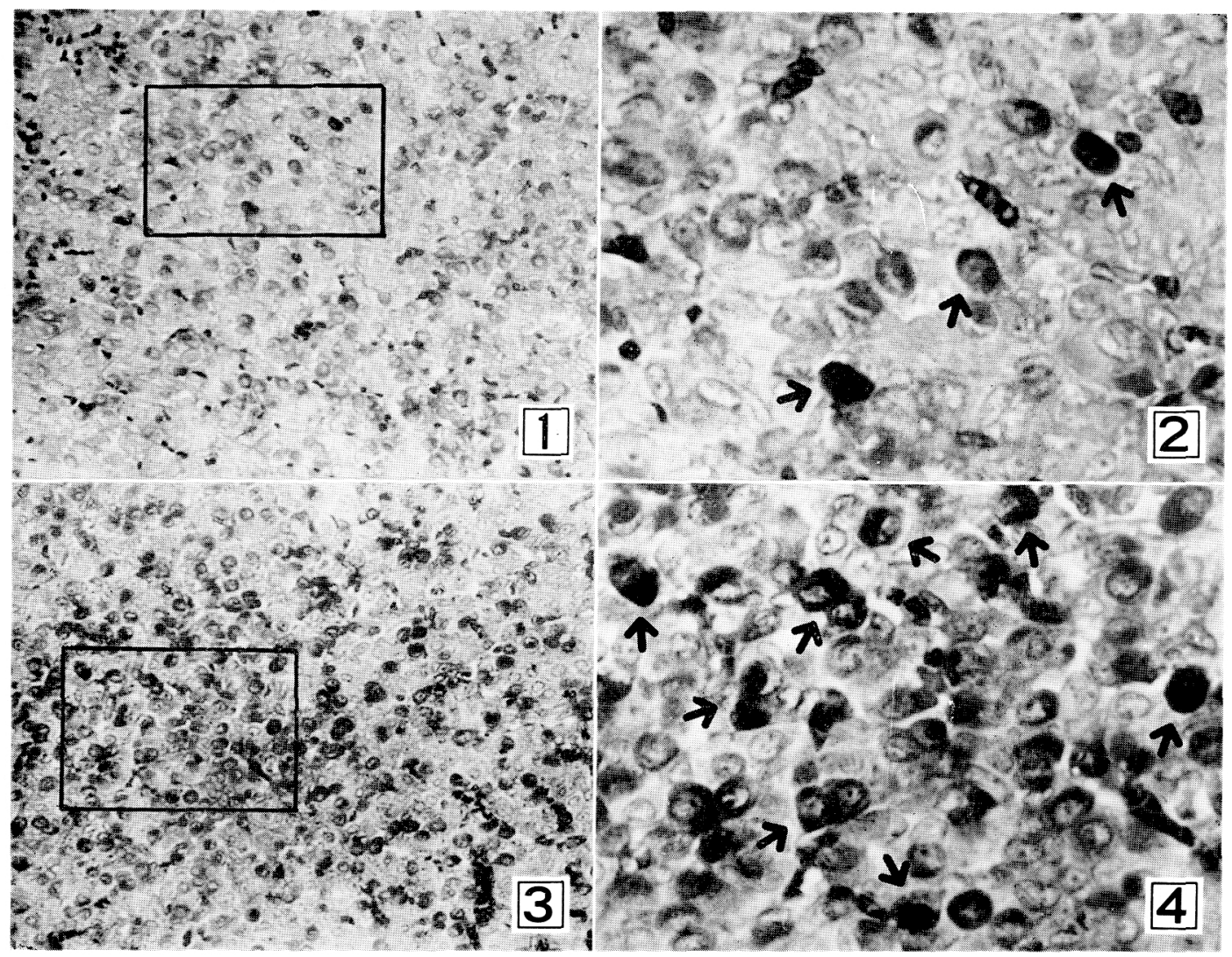

Figs. 1-4. Carmoisine L-positive cells (prolactin cells, arrows) in the central part of the mouse pituitary. Many orange G-positive cells (somatotropes) appear less dark. Small dark dots are erythrocytes. Fig 1. Tumor-free control mouse. $\times 190$. Fig. 2. Part of pituitary shown in Fig. 1, highly magnified. $\times 550$. Fig. 3. Tumor-free mouse subjected to neonatal treatment with $5 \mu \mathrm{g}$ estradiol. The increase in the number of prolactin cells is apparent. $\times 190$. Fig. 4. Part of pituitary shown in Fig. 3, highly magnified. $\times 550$.

the former $(p<0.001)$. The prolactin cell count in tumor-bearing estrogenized mice (combined Groups 2-6) was not significantly higher than that in tumor-bearing controls.

Comparison among groups of tumor-free mice showed that the mean prolactin cell count in estrogenized mice was higher than that in control mice (mice receiving estradiol alone and with prolactin ws. controls, $\mathrm{p}<0.01$, and estradiol plus progesterone $v s$. controls, $\mathrm{p}<0.001)$.

Results of cell counts for gonadotropes in both intact and ovariectomized mice are presented in Table 3 . Neonatal treatment with 5 or $20 \mu \mathrm{g} 17 \beta$-estradiol for 5 days singly and in combination with prolactin and treatment with progesterone resulted in significant decreases in gonadotropes $(p<$ 0.01 ), when compared with controls. Treatment with progesterone plus estradiol resulted in a decrease in gonadotropes, which was not statistically significant. Treatment with prolactin alone had no significant effect. Ovariectomy invariably brought about a significant increase in the number of gonadotropes and the appearance of castration cells of varying degrees of prominence. There was no significant difference 


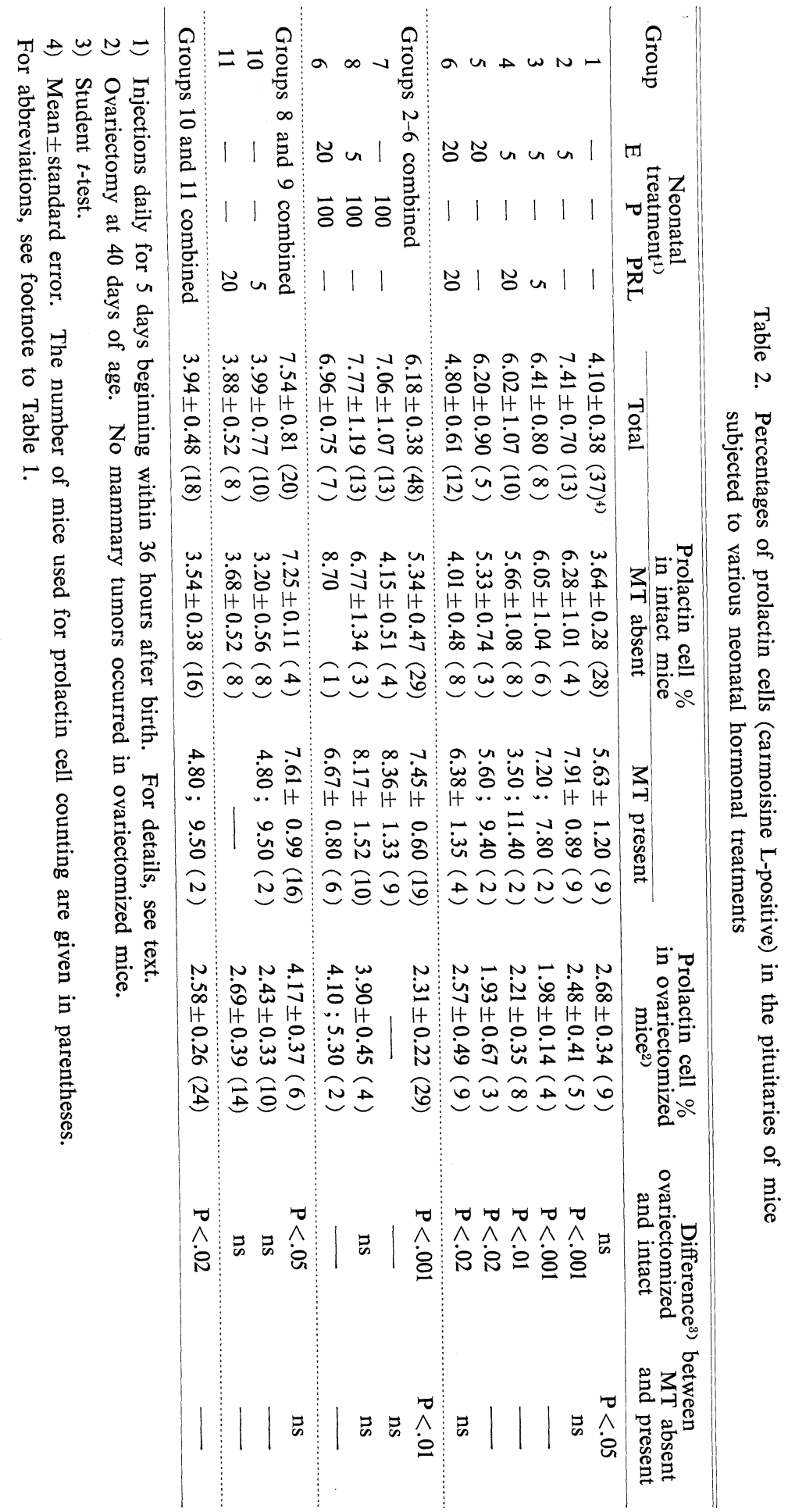


Table 3. Percentages of gonadotropes in the pituitaries of mice subjected to various neonatal hormonal treatments

\begin{tabular}{|c|c|c|c|c|c|}
\hline \multirow{2}{*}{ Group } & \multicolumn{3}{|c|}{ Neonatal treatment ${ }^{1)}$} & \multirow{2}{*}{ Intact } & \multirow{2}{*}{ Ovariectomized $^{2)}$} \\
\hline & $\mathrm{E}$ & $\mathbf{P}$ & PRL & & \\
\hline 1 & - & - & - & $5.37 \pm 0.44(33)^{3)}$ & $18.78 \pm 2.56(10)$ \\
\hline 2 & 5 & - & - & $4.07 \pm 0.51(17)$ & $18.38 \pm 1.57(5)$ \\
\hline 3 & 5 & - & 5 & $4.50 \pm 0.55(8)$ & $19.13 \pm 4.29(3)$ \\
\hline 4 & 5 & - & 20 & $3.71 \pm 0.50(8)$ & $18.02 \pm 2.09(9)$ \\
\hline 5 & 20 & - & - & $3.34 \pm 0.51(8)$ & $7.50 \pm 1.15(3)$ \\
\hline 6 & 20 & - & 20 & $3.97 \pm 0.64(10)$ & $17.76 \pm 1.78(9)$ \\
\hline \multicolumn{4}{|c|}{ Groups $2-6$ combined } & $4.08 \pm 0.17(51)$ & $17.03 \pm 1.12(29)$ \\
\hline 7 & - & 100 & - & $4.04 \pm 0.48(17)$ & $\ldots$ \\
\hline 8 & 5 & 100 & - & $4.36 \pm 0.39(19)$ & $12.73 \pm 1.11(3)$ \\
\hline 9 & 20 & 100 & - & $4.31 \pm 0.71(8)$ & $9.20 ; 10.90(2)$ \\
\hline \multicolumn{4}{|c|}{ Groups 8 and 9 combined } & $4.35 \pm 0.22(27)$ & $11.66 \pm 0.93(5)$ \\
\hline 10 & - & $一$ & 5 & $4.78 \pm 0.47(6)$ & $20.56 \pm 1.80(7)$ \\
\hline 11 & - & - & 20 & $4.83 \pm 0.74(8)$ & $19.90 \pm 1.58(14)$ \\
\hline \multicolumn{4}{|c|}{ Groups 10 and 11 combined } & $4.81 \pm 0.49(14)$ & $20.12 \pm 1.19(21)$ \\
\hline
\end{tabular}

1) Injections daily for 5 days beginning within 36 hours after birth. For details, see text.

2) Ovariectomy at 40 days of age.

3) Mean \pm standard error. The numbers of mice used for gonadotrope counting are given in parentheses.

For abbreviations, see footnote to Table 1.

between tumor-bearing and tumor-free mice. The mean TSH cell counts (not presented in the tables) varied less than those of gonadotropes, ranging from $1.7 \%$ to $4.6 \%$.

\section{Discussion}

Prolactin cells were significantly more numerous in neonatally estrogen-treated and progesterone-treated mice than in control mice. Overall, the prolactin cell counts were greater in tumor-bearing mice than in non-tumor-bearing mice. The data presented herein are largely in accord with a role of prolactin in the increased mammary tumor incidence in neonatally steroidtreated MTV-expressed mice. Neonatal steroid treatment caused a decrease in gonadotrope counts, which may correlate with the minimal constant gonadotropin secretion responsible for constant, albeit minimal, ovarian estrogen secretion (Takasugi et al., 1970). As a consequence, estrogen may result in constant prolactin secretion, which then causes mammary gland stimulation and supports eventual tumorigenesis.

Plasma prolactin levels in $\mathrm{BALB} / \mathrm{cfC} 3 \mathrm{H}$ female mice treated neonatally with estrogen, androgen and prolactin were higher at 2, 7 and 15 months of age than those in the controls at metestrus/diestrus, although they were not generally significantly different from controls at proestrus/estrus (Nagasawa et al., 1978).

Changes in prolactin secretion have been reported in rats given neonatal injections of $17 \beta$-estradiol. This treatment produced a constant stimulation of prolactin secretion (Nagasawa et al., 1973) with serum levels of $17 \beta$-estradiol higher than that in diestrous controls of about 180 days of age (Nagasawa et al., 1974). Pantíc and Genbačev (1972) reported that prolactin cell activity was consistently stimulated in neonatally estrogenized rats of both sexes. In addition, in persistent-diestrous female rats resulting from prolonged neonatal estrogen treatment (Kawashima, 1974; Kawashima et al., 1974) or from complete deafferentation of the 
medial basal hypothalamus (Blake et al., 1972), serum prolactin levels remained at a low-diestrous level and the 'proestrous surge' of prolactin secretion was blocked. Augmentation of prolactin secretion has been reported in normal old female rats in the spontaneous persistent-estrus state (Aschheim, 1962; Clemens and Meites, 1971; Kawashima, 1974; Kawashima et al., 1974). Concentrations of prolactin in the serum and in the hypophysis as determined by radioimmunoassay were greater in normal females in the postreproductive phase of life than in persistent-diestrous rats, male rats and ovariectomized normal rats of the comparable ages. All these differences were considered to reflect differences in circulating estrogen. As expected, ovariectomy of mice at 40 days of age in the present studies resulted in decreased prolactin cell counts and increased gonadotrope counts.

The differential cell counts reported herein provide a semiquantitative expression of histological changes in the pituitary. Increased stainability (prominence) of the pituitary cells need to be viewed with some cautions; cells containing increased secretion may reflect increased synthesis of hormone and/or inhibited release of hormone. Nevertheless, the present histometric data provide some support for the suggestion (Bern et al., 1975; Nagasawa et al., 1978) that increased prolactin levels resulting from neonatal steroid treatment may contribute to the high incidence of mammary tumors in MTV-bearing mice.

\section{Acknowledgements}

Aided by NIH grant CA-05388 to H.A.B. and by U.S.-Japan Cooperative Science Program (NSFRF 39781 to H.A.B. and JSPS-5RO55 to S.K.). L.A.J. was a National Fellowship Fund Fellow. We are grateful to Ms. Anikó Mos, Ms. Patricia N. Young and Ms. Hiroko Nagashima for technical assistance and to Mr. William Young for animal care.

\section{References}

Aschheim, P. (1962). C. R. Acad. Sci. 225, 3053.

Bern, H. A., L. A. Jones, T. Mori, and P. N. Young. (1975). J. Steroid Biochem. 6, 673.

Bern, H. A., L. A. Jones, K. T. Mills, A. Kohrman and T. Mori. (1976). J. Toxicol. Environ. Health Suppl. 1, 103.

Beuving, L. J. and H. A. Bern Estrogen Target Tissues and Neoplasia (edited by T. L. Dao). Univ. Chicago Press, p. 257 (1972).

Blake, C. A., R. I. Weiner and C. H. Sawyer (1972). Endocrinology 90, 862.

Brooks, L. D. (1968). Stain Technol. 43, 41.

Clemens, J. A. and J. Meites (1971). Neuroendocrinology 7, 249.

El Etreby, M. F. and U. Tüshaus (1973). Histochemie 33, 121.

Herlant, M. (1960). Bull. Micr. Appl. 10, 37.

Heston, W. E. (1964). J. Nat. Cancer Inst. 32, 947.

Horrobin, D. F. Prolactin: Physiology and Clinical Significance. MTP Medical and Technical Publ. Co. Ltd., St. Leonardgate, Lancaster, p. 25. (1973).

Jones, L. A. and H. A. Bern (1977). Cancer Res. $37,67$.

Kawashima, S. (1974). Gunma Symp. Endocrinol. 11, 129.

Kawashima, S., T. Asai and K. Wakabayashi Psychoneuroendocrinology (edited by N. Hatotani) Karger, Basel p. 128 (1974).

Liebelt, A. G. and R. A. Liebelt (1961). Cancer Res. $21,86$.

Loeb, L. and M. Moskop Kirtz (1939). Am. J. Cancer $36,56$.

Mallampati, R. S. and D. C. Johnson (1973). Neuroendocrinol. 11, 46.

Meites, J. and J. A. Clemens (1972). Vitamins and Hormones 30, 165.

Meites, J., K. H. Lu, W. Wuttke, C. W. Welsch and S. K. Anadri (1972). Rec. Progr. Horm. Res. 28, 471.

Mori, T. (1968a). Annot. Zool. Japon. 41, 43.

Mori, T. (1968b). ibid. 41, 85.

Mori, T., H. A. Bern, K. T. Mills and P. N. Young (1976). J. Natl. Cancer Inst. 57, 1057.

Mühlbock, O. and L. M. Boot (1959). Cancer Res. 19,402 .

Nagasawa, H., T. Mori, R. Yanai, H. A. Bern and K. T. Mills (1978). ibid. 28, 942.

Nagasawa, H., R. Yanai, S. Kikuyama and T. Mori (1973). J. Endocrinol. 59, 377.

Nagasawa, H., R. Yanai, M. Shodono, T. Nakamura and Y. Tanabe (1974). Cancer Res. 34, 2643.

Neill, J. D. (1972). Endocrinology 90, 1154.

Pantíc, V., and O. Genbačev (1972). Z. Zellforsch. $126,41$.

Rasmussen, A. T. and R. Herrick (1922). Proc. Soc. 
Exp. Biol. Med. 19, 416.

Takasugi, N. (1976). Inter. Rev. Cytol. 44, 193.

Takasugi, N., T. Kimura and T. Mori The Postnatal Development of Phenotype. Butterworths, London, p. 229 (1970).

Welsch, C. W., T. W. Jenkins and J. Meites (1970a).
Cancer Res. 30, 1024.

Welsch, C. W., H. Nagasawa and J. Meites (1970b). ibid. 30, 2310.

Yanai, R. and H. Nagasawa (1972). J. Natl. Cancer Inst. 48, 715. 